\title{
IMPLEMENTASI PESAN MORAL MISI PROFETIK MUHAMMAD MENURUT FAZLUR
}

\section{RAHMAN}

\author{
Lukman Hakim', Dani Ramdani ${ }^{2}$ \\ ${ }^{1}$ Universitas Pamulang (UNPAM), Indonesia \\ ${ }^{2}$ UIN Syarif Hidayatullah Jakarta, Indoesia \\ E-mail: ramadlanriqui@yahoo.com
}

\begin{abstract}
Muhammad's prophetic mission is a mission in an effort to disseminate moral teachings whose roots are found in the teachings of monotheism, as is often emphasized in the Qur'an: efforts to uphold social justice, egalitarianism and protection of the weak. Rahman offers a hermeneutic method to refine the Qur'an and criticize the historical awareness that exists in Muslims. This is done to provide the right meaning for the Qur'an, as well as examine the awareness of the religious traditions of Muslims today. Then Rahman offered the double movement method. This method will be very useful for examining all forms of religious institutionalization established by Muslims today, then confirming it to the time of the Prophet to obtain legitimacy or appropriate reference to religious interpretations. Double movement, intended to provide the right meaning for Muslim efforts to interpret religion based on traditions established by the Prophet: refers to the initial conception that was built by the Prophet and his companions.
\end{abstract}

Keyword: prophetic mission; double movement; hermeneutics; Islam; revelation

\begin{abstract}
Abstrak. Misi profetik Muhammad merupakan suatu misi dalam upaya menyebar-luaskan ajaran moral yang muaranya terdapat dalam ajaran monoteisme, sebagaimana yang sering ditegaskan dalam al-Qur'ân: usaha untuk menegakkan keadilan sosial, egaliterianisme dan perlindungan terhadap yang lemah. Rahman menawarkan metode hermeneutika untuk menfasirkan kembali al-Qur'ân dan mengkritisi kesadaran sejarah yang ada dalam umat Islam. Hal ini dilakukan untuk memberikan makna yang tepat bagi al-Qur'ân, sekaligus memeriksa kesadaran tradisi keberagamaan umat Islam masa kini. Kemudian Rahman menawarkan metode double movement. Metode ini akan sangat berguna untuk memeriksa segala bentuk institusionalisasi keberagamaan yang dibangun oleh umat Islam di masa kini, kemudian mengkonfirmasikannya ke masa Nabi untuk mendapatkan legitimasi atau rujukan yang tepat terhadap interpretasi keberagamaan. Double movement, dimaksudkan untuk memberikan makna yang tepat bagi usaha umat Islam untuk melakukan interpretasi keberagamaan berdasarkan tradisi yang dibangun oleh Nabi: merujuk kepada konsepsi awal yang telah dibangun oleh Nabi beserta para sahabatnya.
\end{abstract}

Keyword: misi profetik; double movement; hermeneutika; islam;wahyu

Permalink/DOI: https://doi.org/10.15408/mimbar.v36i1.13067 


\section{Pendahuluan}

Dalam sejarah perkembangan khazanah peradaban Islam, Fazlur Rahman ${ }^{1}$ mencoba memberikan kritik yang tajam terhadap kegagalan modernisme Islam. Para pembaharu Islam terjebak kepada pengambilan tema-tema spesifik yang justru berangkat dari Barat. Tema-tema tersebut kemudian juga dipaksakan untuk ditarik menjadi problem umat Islam. Tapi apakah seluruh tema tersebut relevan bagi umat Islam? Pada kenyataannya tidak. Bahkan niat tulus dari tokoh-tokoh modernis Islam tersebut malah menuai stigma: agen westernisasi.

Lahirnya kelompok fundamentalisme Islam pun juga tidak membawa hasil yang cukup signifikan dalam pembaharuan wacana intelektualitas Islam. Bagaima-napun, dalam sejarah pembaharuan Islam kontemporer, umat Islam mesti berterima kasih terhadap sikapnya yang militan untuk menegakkan tradisi Islam. Namun, karena sikapnya yang tegas dengan Barat, malah mengaburkan konsepsinya tentang kelangsungan tradisi Islam sendiri. Pada akhirnya, mereka tidak berhasil merumuskan suatu metodologi apapun untuk menjembatani jurang kenestapaan intelektualitas umat Islam dengan Barat. Apalagi, beberapa tema yang diusung melulu diupayakan untuk membedakan diri dengan Barat. Contoh yang dapat disebut antara lain adalah, prakarsanya tentang Bank Islam, demokrasi a la Islam, ekonomi Islam dan lain sebagainya.

Bagaimanapun, terlepas dari pro-kontra gerakan pemikiran pembaharuan pemikiran Islam, bahwa mereka telah meletakkan fondasi quo vadis pemikiran Islam kontemporer. Apresiasi layak diberikan bagi mereka. Sudah menjadi keniscayaan sejarah, meminjam istilah Hegel, bahwa setiap tesa akan melahirkan antitesa. Modernisme pasti akan mendapatkan tantangan dari puritanisme atau tradisionalisme. Namun, apapun tipologi gerakan pembaharuan Islam kontemporer, menurut Rahman telah mengalami kegagalan yang cukup signifikan. Penyebabnya tak lain, karena ia keluar dari tradisi Islam itu sendiri. Kemajuan Barat pada sisi material membuat para pemikir Islam begitu terpesona. Sehingga orientasi pendidikannya selalu di arahkan untuk meraih pesona tersebut (Rahmah, 1982; 90).

Namun demikian, tradisi intelektualitas yang dimiliki oleh umat Islam sekarang adalah sebuah tradisi yang artifisial. Sesungguhnya beberapa pemikir Islam sebelumnya telah menunjukkan kelemahan ini, salah satunya adalah al-Ghazâlî dan Ibn Taymiyyah (Rahmah, 1982; 4). ${ }^{2}$ Karenanya, watak Islam artifisial tersebut mempengaruhi setiap watak intelektual Islam kepada penafsiran keagamaan yang sepotong-potong. Teologi meluruh menjadi teologi dialektis yang melulu mempolemikkan antara transendensi dan imanensi Tuhan. Atau fiqh yang tidak mampu berbicara mengenai keadilan sosial dan korelasinya dengan teologis. Juga dalam sufisme, malah berkembang menjadi tradisi eskapisme sosial dan mencari pendasaran normatifnya pada agama. Rahman, sendiri sesungguhnya tertantang untuk membersihkan tradisi Islam dari unsure-unsur artificial keberagamaan Islam yang cenderung mendominasi tradisi Islam kini.

\footnotetext{
${ }^{1}$ Fazlur Rahman dilahirkan di Pakistan pada tahun 1919. Menurut Syarif Hidayatullah, Fazlur Rahman dilahirkan pada saat umat Islam di Pakistan sedang mengalami tantangan yang demikian besar dari arus modernisasi yang menerpa dunia Islam. Umat Islam dituntut untuk segera mencari peran, menetapkan posisi dan mengokohkan landasan ideologis dalam menghadapi tantangan modernitas dan masa depan yang akan dialaminya. Ia dibesarkan di kalangan Sunni yang bermazhab Hanafi. Pendidikan awal keagamaannya diperoleh dari ayahnya, seorang "kyai” alumnus Deoband. Setelah menamatkan pendidikan menengah, Rahman melanjutkan studinya di Universitas Punjab, mengambil spesialisasi Sastra Arab. Gelar Master diperolehnya dari Universitas tersebut tahun 1942.

${ }^{2}$ Kritik al-Ghazâlî terhadap nalar filosofis merupakan keberatannya bahwa nalar (akal) dapat disandingkan sejajar dengan wahyu Tuhan. Atau kritik Ibn Taymiyyah terhadap para Mursyîd yang di-klaim dalam sufisme populer memiliki posisi yang par excellent setingkat dengan nabi. Karenanya ti-daklah berle-bihan jika, watak intelektual filosofis dan sufisme yang artifisial tersebut mendapat gun -cangan kritik yang hebat dari dua pemikir di atas, karena tidak bersumber dari ajaran Islam. Keduanya berupaya mengembalikan nalar Islam kepada semangat al-Qur'ân dan Sunnah Nabi.
} 
Ketidakmampuan para pemikir kontemporer Islam memahami al-Qur'ân seutuhnya itulah yang sesungguhnya mengundang Rahman untuk merumuskan kembali apa yang hendak disampaikan oleh al-Ghazâlî dan Ibn Taymiyyah. Untuk itu, Rahman menawarkan untuk kembali merujuk pada konsepsi yang ada dalam al-Qur'ân dan merumuskannya dalam suatu tema pembaharuan Islam. Oleh sebab itu, Rahman mengatakan:

Jadi, kita lihat bahwa al-Qur'ân dan asal-usul komunitas Islam muncul dalam sinaran sejarah dan berhadapan dengan latar belakang sosio-historis. Al-Qur'ân adalah respon kepada situasi tersebut, dan untuk sebagian besar ia terdiri dari pernyataan-pernyataan moral, religius dan sosial yang menanggapi problema-problema spesifik yang dihadapkan kepadanya dalam situasi-situasi yang kongkrit. Kadangkadang al-Qur'ân, hanya memberikan suatu jawaban bagi sebuah pertanyaan atau suatu masalah, tetapi biasanya jawaban-jawaban ini dinyatakan dalam batasan-batasan suatu ratio-legis yang eksplisit atau semi eksplisit, sementara ada juga hukum-hukum umum tertentu yang dipermaklumkan dari waktu ke waktu (Rahmah, 1982).

Dalam konteks inilah Rahman menyuguhkan suatu pendekatan teoritis untuk menemukan pesan terdalam dari al-Qur'ân serta semangat moral yang menjadi pendasaran ajarannya. Oleh sebab itu, ia menekankan pentingnya usaha-usaha untuk menafsirkan kembali Islam. Untuk itu Rahman menjelaskan:

Jika pembicaraan yang lantang dan berkesinambungan dari kaum Muslimin tentang kelangsungan hidup Islam sebagai suatu sistem doktrin dan praktek di dunia dewasa ini benarbenar sejati, maka tampak jelas bahwa mereka harus memulai sekali lagi pada tingkat intelektual. Mereka harus secara terang-terangan dan tanpa perlu menahan diri membahas apa yang dikehendaki Islam untuk mereka lakukan dewasa ini. Seluruh kandungan syari'ah mesti menjadi sasaran pemeriksaan yang segar dalam sinaran bukti al-Qur'ân yang sistematis dan berani harus dilakukan. Bahaya terbesar dari pekerjaan ini tentu saja, adalah proyeksi ide-ide subjektif ke dalam al-Qur'ân, menjadikan-nya sebagai objek perlakuan yang arbitrer. Namun proyeksi ide-ide subjektif ini, sebagian besarnya dapat diminimalisasi. Suatu metodologi yang seksama untuk memahami dan menafsirkan al-Qur'ân harus digunakan.

Pertama, suatu pendekatan historis yang serius dan jujur harus digu-nakan untuk menemukan makna teks al-Qur'ân. Aspek metafisis dari ajaran al-Qur'ân mungkin tidak menyediakan dirinya dengan mudah untuk dikena-kan terapi historis, tetapi bagian sosiologisnya pasti menyediakan dirinya. Pertama-tama, al-Qur'ân harus dipelajari secara kronologis. Diawali dengan pemeriksaan terhadap bagian-bagian wahyu yang paling awal akan memberikan suatu persepsi yang cukup akurat tentang dorongan dasar dari gerakan Islam, sebagaimana yang dibedakan dari ketetapanketetapan dan pranata-pranata yang dibangun belakangan. Demikianlah, seseorang harus mengikuti bentangan al-Qur'ân sepanjang karir perjuangan Muhammad. Metode historis ini akan banyak menyelamatkan kita dari ekstravagan dan artifisial penafsiran-penafsiran al-Qur'ân kalangan modernis. Disamping menetapkan makna rincian-rinciannya, metode ini juga akan menunjukkan secara jelas makna ke-seluruhan dari pesan al-Qur'ân dalam suatu cara yang sistematis dan koheren.

Kedua, kemudian seseorang telah siap untuk membedakan antara ketetapan-ketetapan legal alQư'ân dan sasaran-sasaran serta tujuan-tujuan, yang hukum ini diharapkan untuk mengabdi kepadanya. Di sini, sekali lagi, seseorang berhadapan dengan bahaya subjektivitas, tetapi hal ini juga dapat direduksi hingga minimum dengan menggunakan al-Qur'ân itu sendiri. Sudah terlalu sering diabaikan oleh kalangan non-Muslim maupun kalangan kaum Muslimin sendiri bahwa alQur'ân biasanya memberikan alasan-alasan bagi legal spesifiknya. 
Ketiga, sasaran-sasaran al-Qur'ân harus dipahami dan ditetapkan, dengan tetap memberi perhatian sepenuhnya terhadap latar sosiologisnya -yakni lingkungan di mana Nabi bergerak dan bekerja. Hal ini akan mengakhiri penafsiran-penafsiran al-Qur'ân yang subektif, baik oleh kalangan mufassir abad pertengahan ataupun modern -meskipun penafsiran-penafsiran ini tampak koheren dalam dirinya. Jika seseorang dibatasi untuk tidak menyertakan obsesi-obsesi pribadinya ke dalam al-Qur'ân, maka pendekatan semacam ini akan sangat bermanfaat dan, kami yakin, merupakan harapan nyata satu-satunya bagi suatu penafsiran al-Qur'ân yang berhasil dewasa ini. Betapapun, dalam pengertian makroskopis (sebagaimana yang bertentangan dengan perbedaan-perbedaan detil), seluruh penafsiran dan pendekatan terhadap kebenaran adalah subjektif, dan hal ini tak dapat dihilangkan. Setiap pendapat memiliki suatu sudut pandang, dan tidak ada bahayanya dalam hal ini asalkan sudut pandang itu tidak mendistorsi objek pandangan dan juga terbuka bagi visi-visi orang-orang yang memandangnya. Bahkan perbedaan pandapat yang dihasilkannya adalah sehat, asal saja pendapat-pendapat tersebut masuk akal ((Rahmah, 1970; 329).

Dalam pernyataannya di atas, Rahman seperti menawarkan suatu formula hermeneutis dalam penafsiran al-Qur'ân. Hal itu adalah untuk menghindari suatu penafsiran "liar" yang dilakukan oleh penafsir-penafsir modern. Sekalipun al-Qur'ân telah menjadi bagian dari tradisi umat Islam, namun apakah al-Qur'ân (Islam) telah diberikan kesempatan untuk "membicarakan dirinya sendiri"? Yang terjadi justru adalah, seperti dikatakan Ahmad Wahib, "Islam menurut Hamka, menurut Natsir, Abduh, Islam menurut ulama-ulama kuno, dan Islam menurut orang lain. Yang kucari belum ketemu, Islam menurut Allah."(Wahid, 2003;27)

Untuk menghindari subjektivisme dalam penafsiran, Rahman memang mengafirmasi standar penafsiran ortodoksi. Peralatan tersebut mutlak dibutuhkan untuk mengontrol sejauh mana perkembangan ilmu tafsir itu sendiri dan kebenarannya dapat dipertanggungjawabkan. Pertama, tidak hanya penguasaan terhadap bahasa Arab, namun juga idiom-idiom bahasa Arab pada masa Nabi. Kedua, pemahaman terhadap asbâbu 'l-nuzûl untuk menerapkan makna yang tepat di dalam al-Qur'ân. Ketiga, tradisi historis yang berisi laporan-laporan tentang bagaimana orang-orang di lingkungan Nabi memahami perintah-perintah al-Qur'ân. Keempat, setelah ketiganya dipenuhi, barulah nalar diberikan tempat ((Rahmah, 1979; 41).

\section{Double Movemevent: Mencoba Membaca Kembali al-Qur'ân}

Seluruh kerangka metodologis dalam tafsir mesti dimaknai sebagai pemberian sebuah horison tertentu terhadap suatu sudut pandang. Hermeneutika adalah suatu cara untuk menghindari penafisran dari -meminjam istilah Lawrence K. Schmidt- specter of relativism (hantu relativisme) (Hidayat, 2004; 168). Bagaimanapun dalam sebuah penafsiran, relativisme niscaya terjadi, apalagi subjektivisme penafsirnya. Namun jika dibiarkan berkembang secara liar, justru akan "membunuh" otentisitas makna yang hadir dalam teks. Sebuah horison yang ditawarkan dalam hermenutika bukanlah untuk membatasi ruang penafsiran itu sendiri. Yang terjadi malah hermeneutika hendak menawarkan suatu perluasan horison dalam sebuah sudut pandang. Horizon itu sendiri merupakan sebuah tradisi yang hadir di hadapan kita. Tanpa disadari, ia telah menjadi bagian dari kita sendiri.

Dalam tradisi tafsir, baik itu terhadap Bibel atau al-Qur'ân, subjektivisme atau eksklusivitas sebuah teks mungkin terjadi. Eksklusivisme sebuah tafsir menciptakan suatu wacana yang beku dan hampir-hampir identik dengan teks (agama) tersebut. Karenanya, kritik al-Ghazâli dan Ibn Taymiyyah terhadap filsafat dan sufisme populer dapat dianggap sebagai seruan untuk kembali kepada teks yang 
sejati. Di kalangan tradisional, Islam hampir identik dengan fiqh, atau dalam spektrum yang lebih luas adalah syari'ah. Bagaimanapun, sebuah tafsir mestilah menjadi sebuah teks (wacana) yang terbuka. Ia tidak identik dengan teks yang telah ditafsirkan, atau wacana intelektualitas apapun, sekalipun spektrumnya berdasarkan -mungkin—diinspirasikan dari teks yang ditafsirkan. Namun demikian, ia telah menjadi sebuah wacana lain. Keterbatasan horison pemikiran manusia yang disebabkan oleh latar belakang penga-laman dan pengetahuan, akan ikut menentukan ciri atau subjektivitas penafsirnya. Yang mungkin dapat diambil dari sebuah penafsiran adalah, bagaimana si penafsir memberikan world view (weltanschauung, pandangan dunia) terhadap teks yang hadir.

Untuk itu seluruh wacana intelektual dalam Islam, mesti dipandang sebagai produk tafsir terhadap ajaran-ajaran al-Qur'ân dan sunnah Nabi. Jika dalam hermeneutika, problem jarak antara penulis dan pembaca, coba diatasi dan dijembatani. Lalu, dapatkah hermeneutika dioperasionalisasikan dalam konteks al-Qur'ân ini? Tuhan dianggap oleh Umat Islam sebagai pemilik al-Qur'ân, sekaligus "pengarang-nya". Tuhan tidak meruang dan mewaktu: bagi-Nya adalah masa lalu, kini dan akan datang. Dalam konteks hermeneutika zaman romantik atau, dalam istilah Komaruddin Hidayat, psikohistoris, dapatkah Tuhan disejajarkan dengan pengarang dalam tradisi hermeneutis yang telah ada?

Bagaimanapun, konsep hermeneutika tidak dapat diintegrasikan seluruhnya dalam al-Qur'ân. Namun Rahman menandaskan bahwa penafsiran al-Qur'ân harus dilakukan dengan objektif. Dalam konteks ini, Rahman sepakat dengan Betty (2003). Yang dimaksud dengan objektivitas tersebut adalah, menurut Rahman, memastikan arti yang dimaksud dengan pikiran (mind) yang menjadi sumber objek kajian (Rahmah, 1982; 90). Makna yang terkandung dalam al-Qur'ân sudah barang tentu tidak dapat di-cross check dan dikonfirmasikan kepada Tuhan. Seluruh makna yang terkandung dalam al-Qur'ân itu dapat dikonfirmasikan kepada konteks historis di mana Muhammad hidup, demikian menurut Rahman. Kandungan makna yang terintegrasi di dalam al-Qur'ân sudah barang tentu memuat segala aspek normativitas keagamaan. Untuk itu, sejarah hidup Muhammad sangat diperlukan untuk mengetahui bagaimana ia dan para sahabatnya meresponi al-Qur'ân, dan ia inheren ke dalam kognisi pemahaman mereka (Rahmah, 1970; 8).

Dalam konteks inilah sesungguhnya Rahman ingin mengkritik metodologi tafsir kalangan ortodoksi Islam yang mencoba melepaskan kaitan historis al-Qur'ân yang dipahami di masa Nabi dengan masa kini. Respon pemikiran umat Islam periode awal, yang segala fondasinya diletakkan oleh Nabi, adalah suatu yang tidak boleh dilewatkan untuk diketahui dalam proses penafsiran al-Qur'ân. Bagaimanapun, Muhammad telah meletakkan makna yang terkandung dalam al-Qur'ân terbumikan. Ia dapat dipahami oleh komunitas umat Islam periode awal. Dari sana maka al-Qur'ân menjadi sumber normatifitas keberagamaan Islam. Dan segala ketentuan atau usaha Muhammad yang mengintegrasikan ajaran-ajaran al-Qur'ân tersebut disebut sunnah.

Segala penafsiran mengenai al-Qur'ân, seluruhnya berangkat dari objektivisme yang hendak diletakkan oleh panafsirnya terhadap makna yang terintegrasi di dalam ayat-ayat al-Qur'ân. Oleh sebab itu, pemaknaan yang diletakkan dalam tafsir menjadi historis. Dengan demikian, seluruh hasil penafsiran dan kerangka intelektual para mufassir terhadap al-Qur'ân tidaklah absolut. Ia mesti tunduk kepada kenyataan sejarah, sudah barang tentu akan mengalami proses falsifikasi Bagus, 2002; 227). ${ }^{3}$

${ }^{3}$ Diambil dari bahasa Latin, "falsus" (palsu, tidak benar). Dalam konteks filsafat falsifikasi dapat dimengerti sebagai cara memverivikasi asumsi teoritis (hipotesis, teori) dengan menggunakan pelawannya. Ini dilakukan dengan membandingkan asumsi bersangkutan dengan data yang diperoleh melalui eksperimen. Falsifikasi didasarkan pada postulat logika formal. Postulat itu berbunyi bahwa proposisi teoriti s tidak terbukti bila pendapat 
Satu-satunya Kenyataan yang absolut hanyalah milik Tuhan. Manusia hanya sampai pada tahap, bagaimana mendekati-Nya. Dan hasilnya pun belum tentu akan sampai pada derajat kesempurnaan sebagaimana yang dikehendaki oleh Tuhan itu sendiri.

Al-Qur'ân memang telah menstimulasi lahirnya tradisi intelektualitas Islam abad pertengahan: kalâm, falsafah, tashawwuf, fiqh, hadîts, tafsîr, dan lain sebagainya. Seluruh wacana yang dilahirkan dalam perkembangan penafsiran Kitab Suci berkembang menjadi tradisi. Pada awal fase formatif, seluruh tradisi tersebut memang disandarkan pada tradisi yang dilakukan oleh Muhammad dan para sahabatnya. Hal itu disebut dengan sunnah. Namun pada fase post-formatif, justru tradisi-tradisi keilmuan itu semakin mengukuhkan keidentikkannya dengan Islam. Sebagaimana yang digambarkan sebelumnya, fiqh identik dengan Islam itu sendiri, dan lain sebagainya. Dalam konteks ini, tidaklah menguntungkan bagi perkembangan peradaban Islam. Tradisi yang diharapkan berkembang, malah berubah menjadi doktrin yang statis dan kaku.

Untuk itu dalam perkembangan berikutnya, Rahman dalam merespon perkembangan tradisi intelektual Islam, memakai pendekatan Gadamer. Menurut Leonard Binder, hal ini digunakan untuk membedakan antara manivestasi sejarah Islam yang tidak otentik dengan yang otentik (Binder, 2001;425). Hermeneutika yang dimaksud oleh Gadamer syarat dengan kritik terhadap kesadaran sejarah. Karenanya, pendekatan tersebut memang diafirmasi oleh beberapa sarjana Muslim kontemporer untuk meletakkan bagaimana sesungguhnya tradisi Keislaman bergerak dalam bingkai sejarah umat Islam. Salah satunya adalah, sebagaimana dikutip dari Misri A. Muchsin adalah Hasan Hanafi. Baginya ada tiga langkah operasional hermeneutika yang dapat diterapkan secara simultan. Pertama, kritik sejarah, yang menjamin keaslian Kitab Suci dalam sejarah. Kritik sejarah terhadap Kitab Suci dimaksudkan untuk menjaga otentisitas dan kredibilitas dirinya. Kedua, pemahaman yang berkenaan dengan makna dan kondisi sosio-historis di mana Kitab Suci dilahirkan. Ketiga, mengetahui arti yang tepat dari teks (Muchsin, 2002;69).

Rahman hendak meminjam hermeneutika Gadamer dalam pengertian ingin membersihkan wacana (tradisi) Keislaman dari dogma eksklusivitas. Dengan kata lain Rahman hendak membersihkan tradisi keislaman dari tradisi inteletualitas Islam yang artifisial. Bagaimanapun, wacana keberagamaan dalam Islam telah mengalami pembakuan yang begitu statis. Ia hampir-hampir tidak mempan dikritik. Karenanya, hal ini membutuhkan hadirnya sebuah kesadaran sejarah yang otentik, sebagaimana sering diungkapkan oleh Gadamer. Bagaimanapun sebuah kesadaran sejarah semestinya, menurut Binder, terbuka terhadap apa yang hendak dikatakan oleh tradisi tentangnya (Bineder; 429).

Wacana keberagamaan kini, merupakan warisan sejarah Islam masa lampau. Determinisme historis terkadang mengaburkan pandangan mana sesungguhnya tradisi keberagamaan yang hendak dibangun oleh Islam (otentik) dan mana yang mesti ditinggalkan. Wacana keberagamaan, bagaimanapun, lahir dari sebuah respon sejarah. Seperti yang diungkapkan sebelumnya. Pada fase praformatif masyarakat Islam, seluruh tradisi memuara pada tradisi yang diambil dari Nabi. Namun pada perkembangan selanjutnya, seperti yang telah dikatakan Rahman sebelumnya, karena tradisi adalah diam, tidak dapat tidak akan mengalami pergeseran karena penafsiran. Dalam hal ini Rahman sepakat dengan Gadamer, bahwa tradisi yang telah dibangun oleh umat Islam tidak boleh luput dari kritik dan dapat dipertanyakan per definisi (Rahman; 10).

sebaliknya turun dari aneka pernyataan-pernyataan yang cocok satu sama lain, kendatipun pernyataan-pernyataan yang digunakan itu didasarkan pada observasi. 
Tradisi yang hendak dibangun oleh Islam sesungguhnya adalah misi profetik Muhammad itu sendiri. Bahwa Muhammad adalah Nabi yang menyebarkan ajaran normativitas keberagamaan dalam tema-tema kemanusiaan, keadilan sosial, egalite-rianisme dan monoteisme. Sudah barang tentu, pencapaian tradisi dan bangunan pranata inilah yang semestinya yang lebih dominan dalam Islam. Jika terdapat institusionalisasi pada prakteknya dalam sejarah, bagaimanapun merupakan suatu keniscayaan. Institusionalisasi tersebut tidak lain merupakan suatu bentuk penafsiran keagamaan (Ningrat dan Wahid, 2001; xliii). ${ }^{4}$ Tapi, ia bukanlah esensi. Esensi memerlukan suatu bentuk; bentuk tidak sama dengan esensi. Seperti ruh (jiwa) yang menempati ruangnya dalam tubuh: ia dapat dikatakan sebagai manusia.

Dengan demikian, semangat penafsiran mestinya merupakan sebuah pemahaman yang integratif terhadap konsep (makna) normatif yang hendak disampaikan Tuhan dan meletakkan padanannya dengan tradisi (sunnah) Nabi. Produk-produk kesejarahan umat Islam dalam bentuk tradisi, mesti dipahami sebagai sesuatu yang ter-buka. Sehingga ia dapat terus, meminjam istilah Gadamer, diproduksi dalam konteks ruang dan waktu.

Suatu penafsiran yang integratif dapat dilakukan. Rahman menawarkan dengan konsepsinya yang disebut dengan double movement (gerak ganda). Di bawah ini adalah kutipan in extenso dari Rahman:

Pertama, harus memahami arti atau makna dari suatu pernyataan ter-tentu dengan mempelajari situasi atau problema historis di mana pernyataan tersebut merupakan jawabannya. Tentu saja, sebelum mempelajari teks-teks spesifik dalam sinaran situasi spesifiknya, suatu kajian umum mengenai situasi makro dalam batasan-batasan masyarakat, agama, adat istiadat, pranata-pranata bahkan tentang kehidupan secara menyeluruh di Arabia pada saat kehadiran Islam serta khususnya di dan di sekitar Mekkah -dengan tidak mengenyampingkan peperangan-peperangan Persia-Byzantium-harus dila-kukan. Jadi, langkah pertama dari gerakan pertama ini merupakan upaya un-tuk memahami al-Qur'ân secara utuh maupun dalam batasan-batasan ajaran-ajaran spesifik yang merupakan respon terhadap situasi spesifik. Langkah kedua adalah menggeneralisasikan jawaban-jawaban spesifik tersebut dan me-nyatakannya sebagai pernyataanpernyataan yang memiliki tujuan-tujuan mo-ral-sosial umum yang dapat "disaring" dari teks-teks spesifik al-Qur'ân dalam sinaran latar belakang sosio-historis dan rationes legis yang sering dinyata-kan. Benar, langkah pertama -memahami makna teks-teks spesifik al-Qur'ân-itu sendiri mengimplikasikan langkah kedua dan akan membawa kepadanya. Selama proses ini, perhatian harus diarahkan kepada tujuan ajaran al-Qur'ân sebagai suatu keseluruhan hingga setiap arti tertentu yang dipahami, setiap hukum yang dinyatakan, serta setiap tujuan yang dirumuskan akan koheren dengan lainnya. Al-Qur'ân sebagai suatu keseluruhan memang menanamkan suatu sikap yang pasti terhadap kehidupan dan benar-benar memiliki suatu weltanschauung yang konkret; ia juga mendaku bahwa ajarannya "tidak mengandung kontradiksi dalam" tetapi koheren secara keseluruhannya.

Sementara gerakan pertama dimulai dari hal-hal yang spesifik dalam al-Qur'ân ke penggalian dan sistematisasi prinsip-prinsip umum, nilai-nilai, dan tujuan-tujuan jangka panjangnya, maka gerakan kedua harus dilakukan dalam pandangan umum ini ke pandangan spesifik yang harus diformulasikan dan direalisasikan sekaran. Maksudnya, yang umum harus ditubuhkan dalam

${ }^{4}$ Salah satu contoh yang dapat diungkapkan di sini adalah pernyataan yang cukup liberal dari 'Ali 'Abd al-Raziq mengenai kritiknya terhadap konsep politik Islam. Dia mengatakan, "wahyu Ilahi menyerahkan bentuk pemerintahan pada konstruksi pikiran manusia. Nabi Muhammad merupakan pemimpin pemerintahan, sekaligus pemimpin agama, tetapi tidak membangun prinsip-prinsip tertentu bagi pemerintahan selanjutnya." Pernyataan ini dikutip dari, Charles Kurzman, ed., Islam Liberal: Pemikiran Islam Kontemporer tentang Isu-isu Global, terj., E. Kusnadi Ningrat dan Din Wahid, (Jakarta: Yayasan Wakaf Paramadina, 2001), h. xliii 
konteks sosio-historis yang konkret dewasa ini. Hal ini, sekali lagi, mem-butuhkan kajian yang cermat terhadap situasi dewasa ini dan analisa terhadap unsur komponennya, sehingga kita dapat menilai situasi sekarang dan meng-ubahnya sejauh yang diperlukan, dan mendeterminasi prioritas-prioritas baru untuk mengimplementasikan nilai-nilai al-Qur'ân secara segar. Hingga taraf kita mampu mencapai kedua momen dari gerakan ganda ini dan berhasil, maka perintahperintah al-Qur'ân akan menjadi hidup dan efektif kembali.

Momen kedua ini juga akan berperan sebagai pengoreksi hasil-hasil momen pertama, yakni hasilhasil pemahaman dan penafsiran. Karena jika hasil-hasil pemahaman gagal dalam aplikasinya di masa kini, maka tentunya telah terjadi kegagalan dalam menilai situasi saat ini secara tepat atau kegagalan dalam memahami al-Qur'ân (Rahman; 5-7).

Ebrahim Musa (2000) mengomentari metodologi ini sebagai telah memberikan dukungan terhadap khazanah intelektual modern mengambil peran agar menghasilkan kontribusi pemahaman sejarah yang lebih baik. Bahkan, Rahman malah mendukung eks-plorasi intelektual yang terkekang itu bebas dari dogma dan batasan budaya.

Menurut Taufik Adnan Amal (1994), sekalipun metode yang ditawarkan oleh Rahman relatif baru, namun seluruh perangkat ilmiahnya adalah tradisional. Perangkat tersebut adalah, latar belakang sosio-historis kehidupan Nabi, khususnya asbâbu 'l-nuzûl. Hasil yang diperoleh cukup mencengangkan: berupa penyangsian bangunan keberagamaan yang dihasilkan oleh sejarah Islam, khususnya periode pertama gene-rasi Islam (setelah sahabat). Bagaimanapun, dalam konteks inilah sesungguhnya pemikiran dan tradisi Islam dibangun dan berhasil menggugah kesadaran pada generasi sesudahnya. Namun demikian, dalam perjalanan selanjutnya justru dari sinilah, kontinuitas tradisi yang hendak dibangun dalam misi profetik Muhammad terputus. Tradisi tersebut menjadi identik dengan agama itu sendiri, hingga ia sendiri menafikan keniscayaan sejarah yang menolak untuk dikritisi dan "digugat". Rahman mena-warkan, sebagai konsekuensi logisnya adalah upaya merekonstruksi Islam secara total dan tuntas dengan sikap setia terhadap sumber pokok ajaran Islam. Untuk itu Rahman menyatakan, "kesulitan terbesar yang akan dialami bukanlah dalam melaksanakan langkah baru itu sendiri, tetapi mengangkat kaki seseorang dari “genangan lumpur” penafsiran al-Qur'ân lama yang mungkin memiliki banyak mutiara, tetapi secara keseluruhannya lebih banyak menghambat ketimbang menggalakkan pemahaman yang sejati terhadap al-Qur'ân.” (Rahman, 145).

\section{Pesan Moral: Menyingkap yang Normatif Menjadi Historis}

Studi agama merupakan discourse mengenai manusia "menyapa" Tuhannya yang tersembunyi dalam selubung misteri. Ia hadir, dan kehadiran-Nya dapat dirasakan oleh umat manusia. Namun dalam beberapa Kitab Suci, sesungguhnya Tuhan menyatakan kehadiran dirinya dalam semesta raya: Tuhan yang Imanen. Dan karena kehadirannya yang tersembunyi itulah, seluruh argumen "keberadaan-Nya" dikatakan sebagai tafsir. Dalam konsepsi manusia itulah, Tuhan menyejarah: Tuhan yang disapa dalam beragam ritus, bahasa dan tradisi. Hingga kini, studi terhadap agama tetap menarik. Ia tidak hanya menyatakan Tuhan yang imanen, tapi lebih dari itu: konsepsi bagaimana manusia menghayati hidupnya.

Discourse mengenai agama tidak hanya mencakup aspek doktrinal, tapi juga aspek sosio-praktis yang menyertainya (Abdillah, 2000; 8). Segala aspek keberagamaan, bagaimanapun sangat ditentukan oleh beragam kultur yang melatarbelakangi lahirnya agama tersebut. Oleh sebab itu, agama menjadi identik dengan ajaran sang pembawanya. Budhis-me, identik dengan Sidharta Gautama dan Kristen 
dengan Yesus Kristus (Nabi Isa). Atau agama tersebut identik dengan suatu bangsa atau kaum, seperti Yahudi dengan Bani Isra'il dan Hindu dengan bangsa India. Namun yang paling menarik dalam studi agama sesungguhnya adalah dimulai dari prinsip-prinsip ajaran yang telah ditetapkan oleh para pembawa risalahnya, seperti Isa dalam Kristen, Musa pada Yahudi, Budhisme dengan Sidharta, atau Muhammad dengan Islam. Dari mereka, selanjutnya, ajaran tersebut berkembang menjadi tradisi dan kepercayaan yang dianut oleh manusia.

Karenanya, kajian terhadap Islam, tidak mungkin dapat dilepaskan begitu saja dari eksistensi Muhammad sebagai Nabi yang diutus Tuhan untuk menyebarkan risalah-Nya. Hal ini sesungguhnya ditegaskan dalam syahâdatayn. Kalimat tersebut tidak hanya berupa pernyataan eksplisit mengenai kesaksian "adanya" Tuhan dan pengakuan bahwa Muhammad adalah rasul-Nya. Dalam kalimat yang pertama, Nurcholish Madjid (1992;li) menyebutnya sebagai al-nafy wa 'l-itsbât (peniadaan dan peneguhan, negasi dan konfirmasi). Sikap itu merujuk pada inti ajaran Islam yaitu pasrah. Dengan kata lain, tidak ada orientasi hidup selain Tuhan. Sementara syahâdat yang kedua merupakan ketundukan kepada Muhammad sebagai sang pembawa risalah. Ketundukan tersebut diimplikasikan dengan mengaktualisasikan ajaran yang dibawa Muhammad sebagai suatu kebenaran dalam sejarah.

Kenabian merupakan suatu keniscayaan historis. Keniscayaan untuk menjaga umat manusia agar tetap berorientasi menuju pada kesempurnaan spiritual. Untuk itu Tuhan menegaskan dalam alQur’ân, bahwa Nabi Muhammad bertugas untuk menyampaikan kabar gembira dan peringatan kepada umat manusia. Karenanya dalam konstruksi filsofis abad pertengahan (Ibn Sînâ dan al-Fârâbî) mengidentikkan antara Nabi dengan The King of Philosopher (Raja yang Bijaksana).

Rahman tidak menolak pengandaian ini. Bahkan ia mengkritik beberapa per-nyataan kaum Orientalis yang menyebutkan bahwa Muhammad lebih identik dengan pemimpin suatu bangsa (umat), dibandingkan seorang Nabi. Kenabian dalam Islam tidaklah melulu seorang yang menyerukan kepada kehidupan spiritual seperti yang terdapat dalam tradisi Kristiani atau Budhisme. Muhammad adalah manusia yang menyejarah, bahkan terlahir sebagai manusia biasa. ${ }^{5}$ Kalaulah ia diberikan kelebihan oleh Tuhan dengan, dalam konstruksi filsafat, kemampuannya berkomunikasi dengan akal aktif dan mu'jizât, tidak lain sebagai pembeda antara dirinya dengan kalangan awam. Kelebihan tersebut memang mutlak dikhususkan untuk para nabi, karena mereka pengemban tugas menyampaikan risalah kepada umat manusia.

Setiap Nabi sudah barang tentu akan menciptakan pranata sosial dalam setiap konteks zamannya. Karenanya, guna menjaga kelangsungan ini, kenabian menjadi keniscayaan historis yang tak dapat dihindari. Sudah barang tentu, sebuah hukum yang hendak dibangun oleh seorang nabi berfungsi sebagai pengendali kepentingan pribadi yang berlebihan, sekaligus secara pedagogis menuju pada derajat kesempurnaan kemanusiaan. Oleh karena itu, sangat penting bagi pembuat hukum untuk mampu memanivestasikan kepastian-kepastian hukum tersebut dalam prilakunya sendiri, sekaligus mengkomunikasikan terma-terma formal hukum yang dapat diterima oleh nalar umum. Tugas ini, menurut Rahman (1958;53), hanya dapat direalisasikan dengan ketajaman akal dan kekuatan imajinasi seorang Nabi.

Hukum yang hendak diproduk oleh seorang nabi, mesti berangkat dari tradisi yang dipahami dalam konteks masyarakatnya. Hal itu akan memudahkan masyarakat mengadaptasinya ke dalam sebuah tradisi dan inheren, menjadi bagian dari dirinya. Sebuah tradisi kenabian mestilah kelak menjadi

${ }^{5}$ Lihat kutipan ayat dalam Bab III Q.S. al-Kahf (18): 110 dan Q.S. al-Fushshilat (41): 6 
tradisi dalam umatnya. Untuk itu, kemampuan intelligible nabi akan sanggup menerjemahkannya ke dalam konteks sosio-historis masyarakatnya sendiri. Tradisi tersebut mesti berkesinambungan. Karenanya, ketika sang nabi wafat, seluruh tradisi yang telah ditetapkannya dalam konsepsi hukum dapat dilaksanakan dan berkembang di zaman sesudahnya. Tradisi yang diwarisi oleh Muhammad itu kemudian disebut dengan sunnah.

Hal ini dapat dirujuk bagaimana strategi Muhammad untuk menyebarkan risalah Tuhan tersebut. Secara khusus, Muhammad telah berjasa besar melakukan reformasi terhadap kondisi sosiokultural masyarakat Arab. Bahkan menurut Robert N. Bellah, sebagaimana dikutip oleh Nurcholish Madjid (1992; xlv), sangat modern, bahkan terlalu modern untuk zamannya. Dan perjuangan Muhammad untuk mencapai prestasi tersebut tidak akan mungkin dicapai jika tak memiliki imajinasi dan pandangan jauh ke depan mengenai peradaban umat manusia.

Dalam hal penciptaan pranata sosial, menurut Rahman, memang tidak dibangun oleh Muhammad pada periode Mekkah, tapi Madinah (Rahman, 1979; 16). Sekalipun pada periode Mekkah, Muhammad memang mengutuk praktek ribâ. Tapi konstruksi hukum mengenai larangan tersebut belum terbangun. Sebuah penerapan legal-formal harus dilakukan secara gradual. Rahman melihat pelarangan minuman keras merupakan contoh yang menarik dari al-Qur'ân (Rahman, 1979;37-38). ${ }^{6}$ Bisa saja pada periode Mekkah Nabi meletakkan legal-formal keagamaan seketika itu. Namun bagaimana mungkin sebuah risalah yang masih belia dapat direspon dan mendapat simpati dari bangsa Arab ketika itu, jika belum apa-apa, seolah-olah, hendak memaksakan kehendaknya sendiri. Problemnya tidak semata bahwa wahyu belum turun. Tapi lebih pada alasan strategis menyelamatkan perjuangan menyebarkan risalah dan mendapatkan simpati bangsa Arab. Ketika komunitas umat Islam mulai terbentuk di Madinah, barulah legislasi-formal mulai dibangun sedikit demi sedikit. Kini perjuangan Nabi mulai bergeser dari penyampai ajaran spiritual ke pembentukan komunitas Muslim sejati yang diikat dalam sebuah pranata sosial.

Seorang nabi akan membangun sebuah hukum dalam sinaran wahyu Ilahi. Seluruh ketetapan yang dibangun oleh Muhammad, misalnya, pasti merujuk pada respon al-Qur'ân terhadap kondisi sosial masyarakat ketika itu. Karenanya, dalam setiap ayat-ayat hukum, biasanya, diiringi dengan asbâbu 'l-nuzûl (Rahman, 1979; 17), yang menjelaskan latar belakang ayat tersebut turun.' Tapi konteks legalformal suatu ayat hu-kum tidak mesti berlaku statis pada konteks sosio-historis itu saja. Ajaran nabi adalah universal. Ia tidak dapat dibatasi pada ruang dan waktu tertentu. Ia bersifat abadi karena datangnya dari Tuhan.

Strategi Nabi ketika mengikat persaudaraan antara muhâjirûn dan anshâr tidak semata ikatan politis. Tapi lebih berdasarkan sebuah persaudaraan abadi dan universal yang semangatnya diilhami dari al-Qur'ân. Komunitas keberagamaan yang sejati tidak dibangun dalam prinsip hereditas, sebagaimana yang dianut dalam bangsa-bangsa primitif. Tapi lebih pada ikatan primordial yang suci, yaitu pada

${ }^{6}$ Al-Qur'ân pada periode pertama Islam tidak mengharamkan pemakaian alkohol. Kalaulah muncul ayat yang berkenaan dengan ini adalah penjelasan mengenai manfaatnya yang kecil dan baha-yanya yang lebih besar (Q.S. al-Baqarah (2): 219). Hal ini dimaksudkan bahwa al-Qur'an hendak memberikan wacana terlebih dahulu mengenai bahaya minuman keras. Setelah wacana itu tersebar, barulah masuk pada tahapan penciptaan infrastruktur. Yang dimaksud di sini adalah al-Qur' an mela-rang shalat dalam keadaan mabuk. Ketika infrastruktur tersebut established, barulah legalformal (larangan tersebut) direalisasikan. Tuhan berfirman, "Sesungguhnya minuman ke ras, berjudi ... adalah perbuatan keji yang berasal dari Setan...” (Q.S. al-Mâ'idah (5): 90).

${ }^{7}$ Salah satu contoh adalah larangan melaksanakan shalat dalam keadaan mabuk. Hal ini didasari ketika beberapa sahabat melaksanakan shalat dalam keadaan mabuk mengalami kekeliruan yang signifikan dan fatal. Peristiwa ini dilaporkan kepada Nabi. kemudian turunlah ayat tersebut yang mela-rang pelaksanaan shalat dalam keadaan mabuk. 
prinsip monoteisme. Selanjutnya egaliterianisme, di mana setiap individu memiliki posisi yang sama di hadapan Tuhan. Hanya yang bertakwa, yang paling mulia di sisi-Nya.

Strategi penyampaian risalah yang efektif sangat diupayakan oleh Muhammad. Sebagai seorang manusia biasa, ia terlalu cerdas untuk menciptakan sebuah komunitas Muslim. Dan pada awal karir kenabiannya, strategi inilah sesungguhnya yang hendak diupayakan demi akselerasi perkembangan risalah yang tidak hanya da-lam lingkup jazirah Arab, tapi juga seluruh dunia. Bahkan kemudian, perkembangan risalahnya bergerak seperti air bah yang menghantam dinding peradaban yang senyap dari bangunan spiritualitas. Dalam tempo, tidak lebih dari dua dasawarsa, seantero Jazirah Arab, pasrah kepada ajaran Islam. Seorang nabi memang mendapatkan inspirasi perjuangannya dari Tuhan (wahyu). Selain itu, hal ini ditunjukkan dengan bakatnya yang luar biasa dalam mengimplementasikan ajaran Tuhan kepada umat manusia. Sudah barang tentu, sebagai manusia pilihan Tuhan, ia akan dilindungiNya dalam setiap jejak langkah perjuangannya. Namun demikian, strategi yang jitu atau sikap tidak pernah menyerah adalah inti dari sebuah perjuangan untuk menegakkan kalimat-u 'l-haqq.

Lalu bagaimanakah peran wahyu bagi kelanjutan misi profetik Muhammad? Rahman memandang bahwa wahyu, sebagaimana banyak dikatakan oleh filsuf Mus-lim, merupakan perolehan intelektualitas yang paling sempurna, lebih mudah untuk menyatakan bahwa hukum dibangun di atas landasan religius wahyu (Rahman, 1979;57). Oleh karena itu, seorang pembuat hukum yang sejati haruslah seorang nabi-filosof. Dan hukum tersebut mesti didasarkan pada sinaran wahyu Tuhan. Karenanya setiap nabi-filosof yang sejati haruslah seorang pembuat hukum. Seorang nabi sejati atau filsuf asli, semata-mata berkat keberadaannya sebagai nabi atau filsuf, tidak bisa berpangku tangan dalam batas-batas kepribadiannya sendiri, tetapi harus maju ke hadapan umat manusia, atau suatu bangsa, dengan membawa agama yang diwahyukan Tuhan dan hukum yang didasarkan padanya. Selanjutnya Rahman berkomentar, ia harus mampu merumuskan kesadaran religiusnya ke dalam pola kehidupan religio-politis yang pasti untuk diikuti oleh manusia. Dalam konteks ini, pencapaian seorang filsuf atau seorang sufi jelas berbeda pada tingkat kesempurnaannya dengan para nabi. Sekalipun pada tataran spiritualitas, seperti dikatakan dalam banyak doktrin sufisme, seseorang dapat menyamai tingkat perolehan spiritualitas yang dicapai oleh para Nabi.

Dengan adanya wahyu Tuhan, memudahkan para nabi untuk meletakkan misi profetiknya ke dalam pratana-pranata sosial atau hukum tertentu sepanjang dapat diapresiasi oleh komunitasnya. Ibn Sînâ menyebut, sebagaimana dikutip oleh Rahman, bahwa tujuan dari institusionalisasi hukum adalah mempersiapkan manusia bagi tuju-an spiritual. Oleh karena itu secara keseluruhan, tindakan-tindakan keberagamaan bertujuan untuk melestarikan hukum kenabian yang menjamin eksistensi bangsa dan membawa mereka dekat kepada Tuhannya melalui penyucian diri. Singkatnya, Rahman sependapat dengan Ibn Sînâ, bahwa hukum yang dibawa oleh seorang Nabi tidaklah melulu dimaksudkan sebagai pis aller (peace maker, penciptaan kedamaian), melainkan persiapan bagi peningkatan spiritual dan kebahagiaan yang sejati.

Misi profetik Muhammad, tidak dapat dibatasi pada ruang kesejarahan tertentu. Ajarannya bersifat universal. Hal ini memang ditunjukkan oleh al-Qur'ân yang berbahasa sangat simbolistik dan penuh metafora (Rahman, 1958; 41-42). ${ }^{8}$ Karenanya dibutuhkan kreasi umat manusia untuk

${ }^{8}$ Oleh beberapa filsuf Muslim, pendapat ini diamini. Simbolistik dari tanda yang ditunjuk-kan oleh al-Qur'an dan ajaran-ajaran religius menunjukkan bahwa ajaran Islam sangat universal. Ayat-ayat tidak pernah merujuk pada ruang tertentu dan kemudian membingkai dalam ruang kesejarahan. Bahkan, maknanya terus bergerak seiring dengan kemampuan nalar manusia untuk menginterpretasi-kannya ke dalam konteks sejarahnya. Dengan demikian, makna al-Qur'an tidak pernah kering untuk terus digali dalam ruang-waktu sejarah umat manusia. 
mengkontekstualisasi makna universal tersebut ke dalam bingkai kesejarahannya. Rahman menekankan terhadap penafsiran al-Qur'ân yang kontekstual (Rahardjo, 1999; 261).

Namun demikian, Rahman menolak terjadinya suatu relativitas terhadap kebenaran yang terkandung dalam penafsiran al-Qur'ân. Sejak awal, al-Qur'ân menekan-kan pada semangat moral. Suatu ajaran agama, secara esensial, adalah absolut. Absolutisme ajaran al-Qur'ân tersebut terletak pada konsepsinya mengenai monoteisme dan semangatnya pada moralitas (Rahman, 1979; 33). Pada konteks inilah sesungguhnya para Nabi diutus. Selanjutnya seluruh perjuangannya untuk menegakkan risalah Tuhan adalah diinspirasikan untuk menekankan moralitas umat manusia dalam setiap dimensi kehidupannya.

Sejarah perjuangan Muhammad ketika di Mekkah menunjukkan korelasi bahwa ia adalah penganjur dari semangat moralitas yang terkandung dari ajaran yang hendak disampaikannya. Penolakan terhadap risalah Muhammad dari orang-orang kafir Quraisy, sesungguhnya bukan disebabkan oleh faktor penolakan ajaran teologis terhadap yang disampaikan Muhammad. Namun lebih pada konsekuensi dari ajaran moral tersebut. Sudah barang tentu mereka menolak perubahan yang ditawarkan, sementara mereka sangat diuntungkan dengan statu quo. Para aristokrat Quraisy sangat diuntungkan dengan kondisi ketidakadilan sosial. Karenanya, tidaklah men-cengangkan, pengikut Nabi di Mekkah mayoritas terdiri dari kalangan marginal.

Komunitas Muslim yang tercipta di Madinah adalah komunitas etis yang dicita-citakan oleh Muhammad. Jika dalam kenyataannya, bahwa Muhammad mengikat pakta politik dengan penduduk luar Madinah, merupakan suatu strategi untuk menyukseskan risalah kenabiannya. Namun tidak sedikit di antara beberapa kabilah (suku) yang tertarik dengan kesantunan Muhammad dan para sahabatnya, sehingga mereka memasrahkan dirinya ke dalam Islam. Untuk menyelamatkan komunitas Muslim itulah, Muhammad membangun pranata hukum-hukum sosial. Bagaimana-pun, jika sebuah komunitas tidak diikat dalam sebuah institusionalisasi, maka komunitas tersebut akan segera musnah dengan sendirinya. Hal itu disebabkan karena tidak ada hukum yang mengatur dan jaminan keselamatan individu beserta propertinya.

Sesungguhnya konsepsi yang hendak dibangun oleh kalangan pemikir Islam kontemporer, baik modernis ataupun kalangan fundamentalisme Islam, adalah hendak menegaskan kehadiran komunitas Islam yang sejati. Tapi, sebagaimana Rahman mengkritiknya, karena tidak dibangun di atas fondasi yang tepat, maka seluruh bangunan tersebut rubuh seketika. Seluruh fondasi tradisi Islam, hendaklah dibangun dari al-Qur'ân dan sunnah Nabi. Tanpa itu, konsepsi keberagamaan tidak hanya kehilangan otoritas normativitasnya, namun juga kehilangan otentisitasnya sebagai sebuah ajaran keagamaan.

Penekanan misi profetik Muhammad sesungguhnya merupakan kelanjutan dari tradisi kenabian masa lalu yaitu pada penciptaan umat manusia yang lebih bermoral yang semangatnya disinari dari wahyu Tuhan. Bagaimanapun, secara normatif ajaran Tuhan amat universal. Dengan demikian dibutuhkan kehadiran seorang nabi untuk memberikan pendasaran normatif pada setiap perilaku aktual manusia. Untuk itulah kenabian selalu bertugas untuk menyelaraskan yang normatif dan historis. Atau memberikan makna normatif bagi yang historis.

Namun demikian, bentuk legal-formal yang dibangun oleh Nabi banyak disalahartikan sebagai pembakuan yang tak lekang oleh zaman. Rahman menolak argumentasi tersebut. Baginya, sebuah bentuk legal-formal harus harus dapat menjelaskan konsepsi normatif (teologis) yang terdapat dalam alQur'ân(Rahardjo; 263). Hukum yang dimak-sud bukanlah sebuah pelegal-formalan suatu aturan yang 
dikemukakan al-Qur'ân secara skripturalis. Hukum harus berangkat dari etika yang berlaku dalam konteks khazanah kehidupan manusia.

Pesan-pesan etis yang hendak disampaikan al-Qur'ân, bagaimanapun akan tereksklusi oleh fiqh. Fiqh harus dianggap sebagai mewakili pemikiran Islam yang memberikan pendasaran legal-formal terhadap ketentuan-ketentuan etis yang diatur dalam al-Qur'ân. Tujuannya sudah barang tentu agar kehidupan manusia lebih ber-kualitas dan memiliki sandaran normatif. Namun hasil-hasil pemikiran (ijtihâd) dalam fiqh tidak dapat dianggap sebagai yang mutlak. Kebenaran-kebenaran yang dihasilkannya sudah barang tentu dapat dikritisi dan bahkan dapat diubah dalam konteks sosio-kultural tertentu. Sekalipun sebuah ketentuan bentuk legal-formal yang telah diletakkan oleh Nabi sekalipun, ia tetap dapat direkontekstualisasikan ke dalam zaman yang berbeda.

Bagaimanapun, ketentuan legislasi yang telah dihasilkan oleh Muhammad adalah sebuah produk sejarah. Sudah barang tentu substansinya pasti mengikuti zaman di mana Muhammad berada. Secara mutlak yang tidak berubah alah misi profetik Muhammad itu sendiri dalam menegakkan semangat monoteisme dan keadilan sosial. Segala bentuk artikulasi dari semangat itu, diserahkan dalam konteks pemahaman dan keberadaan umat Islam itu sendiri.

\section{Penutup}

Misi profetik Muhammad didasari pada upaya menegakkan semangat etis yang terkandung di dalam al-Qur'ân. Legislasi merupakan suatu bentuk dari ijtihad seorang Nabi untuk menerjemahkan tema-tema etis (normatif) dari ajaran Tuhan. Hingga dengan demikian, ia menjadi anak sejarah, yang sudah barang tentu akan diperlakukan seperti tradisi lainnya yang akan mengalami rekontekstualisasi dan reformasi. Namun, misi profetik adalah universal. Universalitas dari misi profetik tersebut tidak dapat dibatasi oleh produk-produk pemikiran umat manusia. Ia dapat menembus seluruh dimensi historisitas dan abadi. Menurut Rahman, tidak ada yang dapat "membunuh" atau "memusnahkan" hukum moral (Rahman, 1979; 32). Misi inilah yang dibawa oleh Nabi. Karenanya seluruh tema-tema tradisi keberagamaan Islam, hendaknya harus diambil dari semangat ini. Tidak melulu terjebak pada pencitraan atau bentuk Islam statis yang penuh dengan simbol-simbol keberagamaan yang esensinya kering dari semangat al-Qur'an itu sendiri.

Muhammad telah mengajarkan kepada umat manusia bagaimana membentuk sebuah komunitas etis yang tidak didasari pada ketentuan hereditas. Tapi dalam lingkungan semangat tawhîd. Tuhan tidak menegaskan sebuah ketentuan legal-formal apapun bagi manusia untuk merealisasikan semangat etis yang terkandung di dalamnya. Tapi ijtihad manusia sangat dibutuhkan untuk melahirkannya dari rahim al-Qur'ân. Selanjutnya usaha untuk merealisasikan tema-tema etis tersebut, seluruh perjuangan Muhammad dapat diambil contoh dan bagaimana keberhasilannya dalam meletakkan tema-tema tersebut dalam bingkai sejarah umat manusia.

\section{Daftar Pustaka}

A'la, Abd. 2003. Dari Neomodernisme Islam ke Islam Liberal: Jejak Fazlur Rahman dalam Wacana Islam Indonesia, Jakarta: Yayasan Wakaf Paramadina 
Binder, Leonard. 2001. Islam Liberal: Kritik Terhadap Ideologi-Ideologi Pembangunan, terj., Imam Muttaqin, Yogyakarta: Pustaka Pelajar

Hidayat, Komaruddin.2004. Menafsirkan Kehendak Tuhan, Jakarta: Teraju

Kurzman, Charles. ed., 2001. Islam Liberal: Pemikiran Islam Kontemporer tentang Isu-isu Global, terj., E. Kusnadi Ningrat dan Din Wahid, Jakarta: Yayasan Wakaf Paramadina

Lorens, Bagus. 2002. Kamus Filsafat, Jakarta: Gramedia

Madjid, Nurcholish. 1992. Islam Doktrin dan Peradaban, Jakarta: Yayasan Wakaf Paramadina

Moosa, Ebrahim. 2000. Gelombang Perubahan dalam Islam: Studi tentang Fundamentalisme Islam, terj. Aam Fahmia, Jakarta: Rajawali Press

Muchsin, Misri A. 2002. Filsafat Sejarah dalam Islam, Yogyakarta: Arruzz

Permata, Ahmad Norma. 2000. Metodologi Studi Agama, Yogyakarta: Pustaka Pelajar

Rahardjo, M. Dawam. 1999. Intelektual, Inteligensia dan Perilaku Politik Bangsa: Risalah Cendekiawan Muslim, Bandung: Mizan

Rahman, Fazlur. 1970. Islamic Modernism: Its Scope, Method and Alternative, International Journal of Middle Eastern Studies, Jilid I, No. 4

Rahman, Fazlur. 1958. Prophecy in Islam: Philosophy and Ortodoxy, London: George Allen and Unwin Ltd.,

Rahman, Fazlur. 1979. Islam, Chicago: The Chicago of University Press

Rahman, Fazlur. 1982. Islam and Modernity, Transformation of an Intellectual, Chicago: The University of Chicago Press

Wahid, Ahmad. 2003. Pergolakan Pemikiran Islam: Catatan Harian Ahmad Wahib, Jakarta: LP3ES 